University of Nebraska - Lincoln

DigitalCommons@University of Nebraska - Lincoln

Nebraska Game and Parks Commission -- Staff

Research Publications

Nebraska Game and Parks Commission

August 1965

Canine Teeth in Two Nebraska Mule Deer

John P. Weigand

Game Division-District No.4, Route No.4, North Platte, Nebraska

Follow this and additional works at: https://digitalcommons.unl.edu/nebgamestaff

Part of the Environmental Sciences Commons

Weigand, John P., "Canine Teeth in Two Nebraska Mule Deer" (1965). Nebraska Game and Parks Commission -- Staff Research Publications. 19.

https://digitalcommons.unl.edu/nebgamestaff/19

This Article is brought to you for free and open access by the Nebraska Game and Parks Commission at DigitalCommons@University of Nebraska - Lincoln. It has been accepted for inclusion in Nebraska Game and Parks Commission -- Staff Research Publications by an authorized administrator of DigitalCommons@University of Nebraska - Lincoln. 
Made in United States of America Reprinted from Journal of Mammalogy Vol. 46, No. 3, 26 August 1965 p. 528

\section{CANINE TEETH IN TWO NEBRASKA MULE DEER}

During the November 1963 deer hunting season in Nebraska, hunters were required to produce all deer bagged at compulsory check stations. Information regarding species, sex and age of all deer checked was recorded at each station. It was at the North Platte station that the author examined the deer described below. A total of 423 deer, of which 322 were mule deer, were examined at this station.

On 3 November 1963 John S. Meyers of North Platte bagged a male mule deer (Odocoileus hemionus hemionus Rafinesque) that was $4 \frac{1}{2}$ years old, judged by examination of the dentition (Severinghaus, J. Wildlife Mgmt., 13: 195-216, 1949). The deer was shot approximately 15 miles $\mathrm{N}$ and 2 miles W of North Platte in Lincoln County. Upon cutting back the cheek skin to examine dentition on the lower jaw, I observed a pair of small canine teeth protruding from the maxillary. The teeth were not measured, but the exposed portion appeared to be about $5 \mathrm{~mm}$ in length. The teeth were loose and could be moved easily.

On 10 November 1963 Walter D. Kinzler of North Platte bagged a female mule deer, $2 \frac{1}{2}$ years old, in Box Elder Canyon about 12 miles SE of North Platte. I noted and measured a pair of maxillary canines, each $4 \mathrm{~mm}$ long on this animal.

Although maxillary canine teeth have been reported in white-tailed deer (Odocoileus virginianus) by several authors, only two previous observations of maxillary canines in mule deer have been recorded (Nordquist, California Fish and Game, 27: 39-40, 1941). John P. Wetgand, Game Division-District No. 4, Route No. 4, North Platte, Nebraska. Accepted 10 January 1965. 